\title{
PECULIARITIES OF DEVELOPMENT OF POTATO DISEASES ALTERNARIA SOLANI AND PHYTOPHTHORA INFESTANS WHEN APPLYING VARIOUS TYPES OF PLANTS PROTECTION
}

\author{
S. Fedorchuk ${ }^{1}$, O. Trembitska ${ }^{1}$, T. Klymenko ${ }^{1}$, B. Radko ${ }^{1}$, M. Lisovyy ${ }^{2}$ \\ ${ }^{1}$ Житомирський національний агроекологічний університет \\ ${ }^{2}$ Національний університет біоресурсів і природокористування Украӥни
}

\begin{abstract}
Розглянуто головні особливості розвитку збудників хвороб картоплі Alternaria solani ma Phytophthora infestans за використання хімічних, біологічних препаратів та регуляторів росту рослин у лабораторних умовах. За застосування хімічних препаратів Консенто 450 SC, к.с., Акробат МЦ в.г., Антракол 70 WP, з.п. у відповідних концентраціях у лабораторних умовах було зафіксовано їх високу токсичну дію щодо збудників хвороб. В усіх варіантах досліду фунгіциди зумовлювали повне призупинення розвитку гриба. Лише у варіанті із застосуванням Консенто 450 SC на 14-у добу експерименту діаметр міцелію гриба Phytophthora infestans збільшився на 0,5 мм і становив 1,5 мм. Біопрепарати Псевдобактерин-2, в.р., Трихофіт, p., Фітоспорин $-M, n$. також проявили негативну дію на збудників Alternaria solani ma Phytophthora infestans. $3 a$ ефективністю дії щодо Alternaria solani оптимальним був Фітоспорин - M, n. - diaметр колонії гриба становив 17,1 мм, а на контролі (без препарату) - 39,9 мм. Вплив Фітоспорину - M, n. на розвиток гриба Phytophthora infestans також був доволі ефективним. Діаметр колоній у цьому варіанті досягав 19,3 мм на 14-у добу експозиції. Під час вивчення взаємодії регуляторів росту рослин і Alternaria solani в лабораторних умовах встановлено зменшення інтенсивності росту гриба порівняно з контролем. Ефективнішими були Гумісол, р. та Потейтін, в.р. - на 14-у добу експозиції діаметр колонії був у межах 33,4 та 34,6 мм відповідно. Найсильнішу дію щодо пригнічення розвитку гриба Phytophthora infestans проявив препарат Гумісол, p., діаметр колонії становив 43,0 мм на 14-у добу експозиції.
\end{abstract}

\section{Ключові слова: Alternaria solani, Phytophthora infestans, збудники, препарати, живильне} середовище, картопля.

Due to high content of starch, protein and potato bulbs, potatoes are important food for people and feeding animals. It is rightly called the second bread. In European cuisine, over 300 dishes from potatoes are known [8].

Currently, more than 95 percent of potatoes are grown in farms and in private homesteads, where yields averaged 13 tons per hectare, while in Europe 30 tons per hectare. One of the reasons for this low yield is the spread of diseases. At present, there are about 30 disease agents, with annual crop losses between 10 and $60 \%$ [2].

Widespread potato diseases are alternaria and phytophtorosis. Pathogens of Alternaria Alternaria fungi, of which the most dangerous is Alternaria molds. The disease most mani-

(C) S. Fedorchuk, O. Trembitska, T. Klymenko, B. Radko, M. Lisovyy, 2019 fests itself in the phase of plant budding and develops throughout the summer. First, dry, brown spots appear on the lower, and then on the upper leaves, which violate the conditions of photosynthesis of plants and can lead to their death. Fungus, besides leaves, also affects stems and rarely bulb [3].

Most potato plants are affected by latex, the causative agent of which is the Phytophthora infestans fungus. The disease leads to loss of crop due to defeat during vegetation of plants, premature death of the peduncle during the formation of tubers, as well as during their harvesting and storage [6].

Despite some differences in the nature of the development of these diseases, which have much in common in the spread of infection, and therefore, to suppress their spread and development, the same chemical and biologi- 
cal measures are used to protect against the agents of these diseases [7].

Measures to combat alternatives and potato lizards require research, namely, the study of effective and long-lasting action of plant protection products against these diseases. It deserves attention to the study of the use of new agents of chemical and, in particular, agents of biological origin and plant growth regulators, which contribute to obtaining an environmentally safe potato harvest [4].

However, it is advisable to admit that in Ukraine, the alternative potato has been insufficiently investigated. The availability of experimental data in this area is significantly inferior to the study of potato late blight, although the spread and harmfulness of these two diseases are quite similar, which is probably due to the underestimation of the harmfulness of these diseases.

Therefore, the purpose of the work was to conduct research on the use of chemical and biological preparations and PPP against pathogens of potato diseases Alternaria solani and Phytophthora infestans.

\section{MATERIALS AND METHODS OF RESEARCH}

The experiments were carried out in laboratory conditions at School of Selection and Biotechnology of Zhytomyr National Agroecological University in 2013-2015. For the identification of fungi, standard techniques of V.I. Bilai (1982) [1] were used. The object of the research was the pathogens of alternariazo and potato phytophagous diseases - Alternaria solani and Phytophtora infestans on the leafy surface of plants. Sowing of pathogens into the nutrient medium was carried out in sterile Petri dishes on potato-glucose agar (KGA) of the following composition: $20 \mathrm{~g}$ of agar and $20 \mathrm{~g}$ of glucose were added to 11 of potato broth ( 11 of water +200 grams of potatoes). One of the fungicides, biopreparations and PPP was introduced into the nutrient medium in the concentrations recommended by the manufacturer and the same doses [5]. Control was the cups with the environment without adding drugs. The resulting mixture was poured into sterile Petri dishes, which were kept in an incubation chamber for three days to check their purity. On the surface of the nutrient medium a purifying needle was applied to a pure culture of pathogens of alternaria and phyllotrophy. In control, pathogens were sown on a clean nutrient medium. Soaked in such a way Petri dishes were kept at a temperature of $+24^{\circ} \mathrm{C}$. The records of the diameter of the colonies of Alternaria solani and Phytophtora infestans were carried out on the 7 th and 14th day. The repetition of the experiment is fivefold.

Among the chemical agents we studied Consento $450 \mathrm{SS}(0.1 \mathrm{mg} / 25 \mathrm{ml}$ medium), Acrobat MC (0.1 g/25 ml medium), Anthracol $70 \mathrm{WP}(0.075 \mathrm{~g} / 25 \mathrm{ml}$ medium $)$; of biological - Pseudobacterin-2 $(0.005 \mathrm{ml} /$ $25 \mathrm{ml}$ of medium), Trihofit $(15 \mathrm{ml} / 25 \mathrm{ml}$ of medium), Phytosporin - M. p. (0.004 ml/ $25 \mathrm{ml}$ of medium); PPP was used by Poteitin, (at a concentration of $0.001 \mathrm{ml} / 25 \mathrm{ml}$ of medium), Gumysol (at a concentration of $5 \mathrm{~g} /$ $25 \mathrm{ml}$ of medium), Biolan (at a concentration of $0.003 \mathrm{ml} / 25 \mathrm{ml}$ of medium).

\section{RESULTS AND DISCUSSIONS}

When testing chemical preparations Consent 450 SC, Acrobat MC, Anthracol 70 WP in laboratory conditions, we noted their high toxicity in relation to the pathogens Alternaria solani and Phytophthora infestans on the leafy surface of plants (Table 1).

In all variants of the experiment, fungicides completely stopped the development of Alternaria solani fungus. Only in the version with the use of Consento $450 \mathrm{SC}$ on the fourteenth day of the experiment, the diameter of the mycelium of Phytophthora infestans fungus was $1.5 \mathrm{~mm}$, which is $0.5 \mathrm{~mm}$ more compared to other variants of the experiment.

Consequently, all fungicides of chemical origin such as Consento $450 \mathrm{SC}$, Acrobat MC, Antratol $70 \mathrm{WP}$ in concentration in accordance with the recommended standard have shown a high efficiency in limiting the development of pathogens in leafy potatoes.

The study on the effects of biologically active drugs such as Pseudobacterin-2, Trihofit, Phytosporin-M, on the development of Alternaria solani and Phytophthora infestans in concentrations according to the recom- 
Table 1

\section{Influence of chemical origin agents on the development of molds Alternaria solani and Phytophthora infestans in feeding environment}

\begin{tabular}{l|c|c|c|c}
\hline \multirow{2}{*}{ Fungicides } & \multicolumn{3}{|c}{ Diameter of colony, mm } \\
\cline { 2 - 5 } & \multicolumn{2}{|c}{ Alternaria solani } & \multicolumn{2}{c}{ Phytophthora infestans } \\
\cline { 2 - 5 } & \multicolumn{2}{|c}{ exposition } & 7 days & 14 days \\
\cline { 2 - 5 } & 7 days & 14 days & 18.2 & 48.2 \\
\hline \hline Control & 21.8 & 39.9 & 1.0 & 1.5 \\
\hline Consento 450 SC & 1.0 & 1.0 & 1.0 & 1.0 \\
\hline Acrobat MC & 1.0 & 1.0 & 1.0 & 0.1 \\
\hline Anthracol & 1.0 & 1.0 & & 1.0 \\
\hline HIP $_{05}, \mathrm{~mm}$ & & 0.1 & & \multicolumn{2}{c}{} \\
\hline
\end{tabular}

mended norms also revealed a negative effect on pathogens potato leaves.

As to the effectiveness of the action against the pathogen Alternaria solani Phytosporin$\mathrm{M}$ was the best, the diameter of the colony of the fungus at 14 days of studies was $17.1 \mathrm{~mm}$, while in the control (without the agent) this figure was $39.9 \mathrm{~mm}$ (Table. 2).

Somewhat less effective were Pseudobacterium-2, And Trihofit, the diameter of Alternaria solani fungus colonies at the 14 th day of the study was $20.0 \mathrm{~mm}$ and $25.7 \mathrm{~mm}$.

In our studies, biopreparations also showed the effectiveness of inhibition in the deve- lopment of mycelium fungus Phytophthora infestans. Adding to the nutritional medium of the drug Phytosporin - M, p. was the most effective in comparison with other drugs. The diameter of the colonies in this variant reached $19.3 \mathrm{~mm}$ on the 14th day of the experiment.

When using Pseudobacterium-2 and Trichophyta the diameter of the Phytophthora infestans micelles colonies increased to $25.2 \mathrm{~mm}$ and $31.7 \mathrm{~mm}$, respectively.

Consequently, the use of biological agents suppresses the development of mycelium of pathogens alternaria and latex, which indicates their significant efficiency.

Table 2

\section{Influence of biologics on the development of fungi Alternaria solani and Phytophthora infestans in feeding environment}

\begin{tabular}{l|c|c|c|c}
\hline \multirow{2}{*}{ Agents } & \multicolumn{3}{|c}{ Diameter of colony, mm } \\
\cline { 2 - 5 } & \multicolumn{2}{|c|}{ Alternaria solani } & \multicolumn{2}{c}{ Phytophthora infestans } \\
\cline { 2 - 5 } & \multicolumn{2}{|c|}{ exposition } & 7 days & 14 days \\
\cline { 2 - 5 } & 7 days & 14 days & 18.2 & 48.2 \\
\hline \hline Control & 21.8 & 39.9 & 7.4 & 25.2 \\
\hline Pseudobacterin-2 & 11.8 & 20.0 & 8.7 & 31.7 \\
\hline Trihofit & 15.5 & 25.7 & 5.1 & 19.3 \\
\hline Phytosporin-M & 9.7 & 17.1 & 2.7 & 3.0 \\
\hline
\end{tabular}


Table 3

The influence of PGR on the development of Alternaria solani and Phytophthora infestans fungi in feeding environment

\begin{tabular}{l|c|c|c|c}
\hline \multirow{2}{*}{ PGR } & \multicolumn{4}{|c}{ Diameter of colony, mm } \\
\cline { 2 - 5 } & \multicolumn{2}{|c|}{ Alternaria solani } & \multicolumn{2}{c}{ Phytophthora infestans } \\
\cline { 2 - 5 } & \multicolumn{2}{|c}{ exposition } & 7 days & 14 days \\
\cline { 2 - 5 } & 7 days & 14 days & 18.2 & 48.2 \\
\hline \hline Control (no agent) & 21.8 & 39.9 & 16.4 & 45.0 \\
\hline Poteitin & 15.8 & 34.6 & 15.2 & 43.0 \\
\hline Gumysol & 17.8 & 33.4 & 18.0 & 47.5 \\
\hline Biolan & 19.7 & 38.2 & & 1.8 \\
\hline HIP $_{05}$, MM & & 1.4 & & \\
\hline
\end{tabular}

Results of research on the influence of growth regulators: Gumysol, Poteitin, v.r., Biolan, v.s.r. on the development of Alternaria solani and Phytophthora infestans in the nutrient medium are presented in the table 3.

Studies have shown that the effect of growth regulators on the development of Alternaria solani and Phytophthora infestans fungi was different.

In the study of PGR with respect to the restriction of the development of the Alternaria solani in the laboratory, a decrease in the intensity of growth of mycelial fungus in comparison with the control was found.

Gumisol and Poteitin agents were more effective. where on the 14th day of our research the diameter of the colony was within the limits of $33.4 \mathrm{~mm}$ and $34.6 \mathrm{~mm}$, respectively. In the application of Biolan the diameter of Alternaria solani mycelium reached $38.2 \mathrm{~mm}$, which was, practically, at the control level (without the agents) $-39.9 \mathrm{~mm}$.

The best effect in suppressing the development of Phytophthora infestans was shown by Gumisol: the diameter of the colony was $43.0 \mathrm{~mm}$ on the 14th day of exposure. Somewhat less effective were discovered by Poteitin, in. (diameter of the colony $45.0 \mathrm{~mm}$ ) and Biolan (diameter of the colony $47.5 \mathrm{~mm}$ ). In the control version (without the preparation) during this time the diameter of mycelium was the largest and amounted to $48.2 \mathrm{~mm}$.

Thus, among growth regulators, the most effective against the suppression of the development of Phytophthora infestans was Gumysol, and in relation to Alternaria solani Gumysol and Poteitin.

Despite the fact that the investigational drugs have different active substances, each of the groups - chemical, biological and PPP, practically, have the same effect on pathogens Alternaria solani and Phytophthora infestans.

\section{CONCLUSIONS}

All fungicides of chemical origin such as Consento 450 SC, Acrobat MC, Anthracol 70 WP for efficiency were equivalent and showed high efficacy (100\%) in laboratory conditions in terms of limiting the development of pathogens of leaf diseases potatoes

The use of biological agents also inhibited the development of fungal pathogens, indicating their effectiveness. The best effect was shown by Phytosporin.

Among PGR, the most effective as to development of Phytophthora infestans was Gumysol, and in relation to Alternaria sola$n i-$ Gumisol and Poteitin. 


\section{ЛІТЕРАТУРА}

1. Биопрепараты для защиты картофеля от болезней / Л.И. Пусенкова, В.М. Глез, В.Н. Зейрук и др. // Защита и карантин растений. - 2010. № 10. - C. 26-28.

2. Ганнибал Ф.Б. Видовой состав, таксономия и номенклатура возбудителей альтернариоза листьев картофеля / Ф.Б. Ганнибал; под ред. А.П. Дмитриева // Лаборатория микологии и фитопатологии им. А.А. Ячевского ВИЗР. История и современность. - СПб.: ВИЗр, 2007. - С. 142-148.

3. Фітопатологія : навч. посіб. / І.Л. Марков та ін. - К.: Лipa-К, 2017. - 320 с.

4. Сергієнко В.Г. Вплив сортових особливостей на розвиток сухої плямистості картоплі В.Г. / Сергієнко, С.В. Богданович // Захист і карантин рослин. -2012. - Вип. 58. - С. 192-200.

5. Кузнецова М.А. Фитофтороз и альтернариоз карто- феля: программа защитных действий / М.А. Кузнецова, Б.Е. Козловский, А.Н. Рогожин // Картофель и овощи: науч.-произв. и попул. журн. 2010. - № 3. - С. 27-30.

6. Шевелуха В.С. Состояние и перспективы исследований и применения фиторегуляторов в растениеводстве / В.С. Шевелуха, И.К. Блиновский // Регуляторы роста растений. - М.: Агропромиздат, 2004. - С. 10-35.

7. Бородай B.В. Поширеність та розвиток хвороб картоплі (Solanum tuberosum) в Україні / В.В. Бородай, А.I. Парфенюк // Агроекологічний журнал. - 2018. - № 4. - С. 82-87.

8. Иванюк В.Г. Защита картофеля от болезней, вредителей и сорняков / В.Г. Иванюк, С.А. Банадысев, Г.К. Журомский. - Минск: Белпринт, 2005. $-696 \mathrm{c}$.

\section{REFERENCES}

1. Pusenkova, L.I. et.al. (2010). Biopreparaty dlya zashity kartofelya ot boleznej [Biopreparats for protection of potato from diseases]. Zashita $i$ karantin rastenij - Protection and plant quarantine, 10, 26-28 [in Russian].

2. Gannibal, F.B. (2007). Vidovoj sostav, taksonomiya i nomenklatura vozbuditelej alternarioza listev kartofelya [Species composition, taxonomy and nomenclature of pathogens alternatives to potato leaves]. Laboratoriya mikologii $i$ fitopatologii im. A.A. Yachevskogo VIZr. Istoriya i sovremennost. A.P. Dmitrieva (Ed.). Sankt-Peterburg: VIZr [in Russian].

3. Markov, I.L., Bashta, O.V., Hentosh, D.T. et al. (2017). Fitopatolohiia: navch. pidruchnyk [Phytopathology: teach. textbook]. Kyiv: Lira-K [in Ukrainian].

4. Serhiienko, V.H., Bohdanovych, S.V. (2013). Shkidlyvist sukhoi pliamystosti kartopli [Purity of dry potato spot]. Zakhyst i karantyn roslyn. - Plant protection and quarantine, 59, 231-237 [in Ukrainian].
5. Kuznecova, M.A. et al. (2010). Fitoftoroz i alternarioz kartofelya: programma zashitnyh dejstvij [Phytophtora and alternaria of potato: a program of protective actions]. Kartofel $i$ ovoshi - Potatoes and vegetables, 3, 27-30 [in Russian].

6. Sheveluha, B.C., Blinovskij, I.K. (2004). Sostoyanie i perspektivy issledovanij i primeneniya fitoregulyatorov $\mathrm{v}$ rastenievodstve [The state and prospects of research and application of phytoregulators in plant growing]. Regulyatory rosta rastenij. Moskva: Agropromizdat [in Russian].

7. Borodai, V.V., Parfeniuk, A.I. (2018). Poshyrenist ta rozvytok khvorob kartopli (Solanum tuberosum) v Ukrainy [Prevalence and development of Solanum tuberosum potato diseases in Ukraine]. Ahroekolohichnyi zhurnal - Agroecological journal, 4, 82-87 [in Ukrainian].

8. Yvaniuk, V.H., Banadysev, S.A., Zhuromskyi, H.K. (2005). Zashchyta kartofelia ot boleznei, vredytelei y sorniakov [Protecting potatoes from diseases, pests and weeds]. Mynsk: Belprynt [in Russian]. 